\title{
ЦЕРЕБРОПРОТЕКТОРНОЕ ДЕЙСТВИЕ ПРОИЗВОДНОГО ПИРОГЛУТАМИНОВОЙ КИСЛОТЫ В УСЛОВИЯХ ЭКСПЕРИМЕНТАЛЬНОГО НАРУШЕНИЯ МОЗГОВОГО КРОВООБРАЩЕНИЯ
}

\author{
О.И. Назаров' , Д.А. Бакулин', И.Н. Тюренков' , А.Ю. Вигоров², \\ И.А. Низова ${ }^{2}$, В.П. Краснов ${ }^{2}$ \\ ${ }^{1}$ Кафедра фармакологии и фармации Института НМФО, ВолгГМУ, \\ 400131, Россия, Волгоград, площадь Павших Борцов, д. 1. \\ ${ }^{2}$ Институт органического синтеза им. И.Я. Постовского Уральского отделения Российской \\ академии наук, 620137, Россия, Екатеринбург, ул. Софьи Ковалевской, д. 22/20.
}

DOI: 10.19163/MedChemRussia2021-2021-373

E-mail:mbfdoc@gmail.com

Цель терапии нарушений мозгового кровообращения (НМК) - предупреждение или замедление повреждения ткани мозга и функциональное восстановление нейронов. Эффективность средств, применяемых при лечении НМК не удовлетворяет ни врачей, ни пациентов. Поэтому поиск веществ с нейропротективным действием остается актуальной проблемой [1]. Производные пироглутаминовой кислоты обладают широким спектром активности, в том числе антиагрегантным и ноотропным действием [2, 3], что делает их перспективными для исследования церебропротекторного потенциала. Ранее, среди производных пироглутаминовой кислоты были выделены соединения, которые наряду с ноотропной активностью [4] проявляли антитромботические свойства.

В данном исследовании представлены данные о их влиянии на динамику неврологических нарушений при остром НМК и курсовом введении. Острое НМК вызывали одномоментной двусторонней перевязкой общих сонных артерий. 0 церебропротекторной активности судили по уровню неврологического дефицита после 7 дней лечения, оценивая двигательную активность, координацию, сенсорно-моторную и когнитивную функции. В результате исследования отмечено сопоставимое с цитиколином церебропротекторное действие соединения IAN-1423 [(2S,4S)-4-амино- $N$-(4-фторфенил)пироглутаминовая кислота], что проявлялось в повышении двигательной активности, улучшении сенсорно-моторной и когнитивной функции по сравнению с контрольной группой. Таким образом, производные пироглутаминовой кислоты представляют интерес для разработки на их основе средств для коррекции последствий НМК.

Работа выполнена при финансовой поддержке РФФИ (грант 20-43-660045 р_а).

\section{Литература}

[1] А.В. Концевая, О.М. Драпкина, Ю.А. Баланова, и др. Рациональная фармакотерапия в кардиологии. 2018, 14(2), 156-166.

[2] A. Misra, K.S. Anil Kumar, M. Jain, et al. Eur. J. Med. Chem. 2016, 110, 1-12.

[3] О.А. Громова, И.Ю. Торшин, А.Г. Калачева и др. Журнал неврологии и психиатрии им. С.С. Корсакова. 2016, 116(12), 96-103.

[4] А.Ю. Вигоров, В.П. Краснов, И.А. Низова и др. Доклады Российской академии наук. Химия, науки о материалах. 2020, 494(1), 9-14. 